\title{
Assessing Biodiversity from Space: an Example from the Western Ghats, India
}

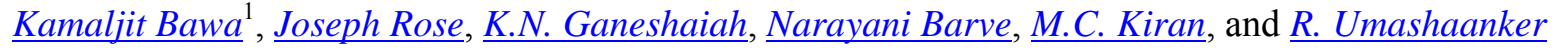

\begin{abstract}
We demonstrate for the first time the potential use of satellite imagery to characterize areas of high and low species richness of trees in tropical forests. Our studies, conducted in the Biligiri Rangaswamy hills in the Western Ghats, India, show a high positive correlation between species richness and the Normalized Difference Vegetation Index (NDVI), which is an index of green biomass. We discuss the application of NDVI values for biodiversity assessment and monitoring, as well as for conservation planning. The NDVI is a rough measure of green biomass.
\end{abstract}

\section{INTRODUCTION}

Biodiversity losses around the world continue to mount despite considerable efforts to protect species and wildlands. According to the latest FAO report (FAO 2000), the annual rate of deforestation in the world during 1990-2000 was 9.4 million ha, and a recent report issued by the IUCN (Walter and Gillett 1998) indicates that one out of every eight plant species is endangered or threatened with extinction. Rapid assessment and monitoring of biodiversity, particularly in the tropics, is critical for conservation planning, but we lack methods to delineate areas with high levels of biodiversity at large spatial scales without intensive, time-consuming ground surveys. Although remote sensing imagery has greatly enhanced our ability to monitor biodiversity losses at the landscape level, such imagery has not yet been used to differentiate areas with varying levels of species richness or biodiversity within a landscape in the tropics. Here we demonstrate for the first time the potential use of satellite imagery to characterize areas of high and low species richness of trees in tropical forests where biodiversity losses are high. We also discuss the application of our technique for biodiversity assessment and monitoring, as well as for conservation planning.

\section{METHODS}

We divided the Biligiri Rangaswamy Temple Wildlife Sanctuary, in Karnataka, India (Lat. $11^{\circ} 43^{\prime}$ to $12^{\circ} 08^{\prime}$ $\mathrm{N}$ and Long. $77^{\circ}$ to $77^{\circ} 16^{\prime} \mathrm{E}$ ), approximately $540 \mathrm{~km}^{2}$ in size, into $1472 \times 2-\mathrm{km}$ grid cells. The size of the cells was determined by the number of plots that could be sampled within a reasonable time.

The Normalized Difference Vegetation Index (NDVI), an index of green biomass, was calculated by using cloud-free IRS 1C LISS III images, with a spatial resolution of $23.5 \mathrm{~m}$, from three different seasons: February 2, 1998; November 16, 1998; and April 15, 1999. The images were processed using ERDAS Imagine software. February marks the start of the dry season, April marks its peak, and November is the earliest month following the monsoons that a cloudfree image can be obtained. Thus, imagery captured during these 3 months shows the annual variation in NDVI. The April image was geo-coded using five 1:25,000 and one 1:50,000 Survey of India(SOI) toposheets. The projection was polyconic and the RMS error was $6.81 \mathrm{~m}$ or 0.2961 pixels. The other two images were registered to this reference image. The RMS errors were 0.097 and 0.0833 pixels, respectively.

The NDVI of each image was calculated using the formula: NDVI $=(\mathrm{NIR}-\mathrm{R}) /(\mathrm{NIR}+\mathrm{R})$; Where NIR $=$ Near Infrared Band, and $\mathrm{R}=$ Red Band. The mean NDVI of three reasons for each pixel was calculated and then the mean NDVI of all pixels falling in each cell $(2 \times 2 \mathrm{~km})$ was determined. This value was correlated with the tree species richness of each cell $(\mathrm{N}=134$ cells). There are four types of forests found on the study site: scrub, dry deciduous, moist deciduous, and evergreen. Many cells have more than one

${ }^{1}$ University of Massachusetts 
vegetation type. Thus, they were categorized according to whichever vegetation type occupied more than $60 \%$ area of the cell. In 45 cells, no one particular vegetation type occupied more than $60 \%$ of the cell area. These cells were removed from the analysis.

Table 1. Basic parameters of plots on the ground (values in parentheses are the ranges for the corresponding parameters)

\begin{tabular}{lcccc}
\hline $\begin{array}{c}\text { Vegetation } \\
\text { type }\end{array}$ & $\begin{array}{c}\text { Number } \\
\text { of plots }\end{array}$ & $\begin{array}{c}\text { Average basal } \\
\text { area }\left(\mathbf{m}^{\mathbf{2}}\right) \\
\text { /plot }\end{array}$ & $\begin{array}{c}\text { Average number } \\
\text { of individuals } \\
>\mathbf{1 0 ~} \mathbf{~ c m ~ d b h} / \mathbf{p l o t}\end{array}$ & $\begin{array}{c}\text { Total number } \\
\text { of tree species }\end{array}$ \\
\hline Scrub & 13 & 0.0571 & $4.23(0-22)$ & $14(0-11)$ \\
Dry Deciduous & 27 & 0.1211 & $9.85(0-33)$ & $26(0-11)$ \\
Moist & 41 & 0.7181 & $19.15(4-33)$ & $74(1-19)$ \\
Deciduous & 8 & 0.6656 & $31.37(20-45)$ & $25(8-14)$ \\
Evergreen & & & \\
\hline
\end{tabular}

Fig. 1. Relationships between NDVI and species diversity in different vegetation types.

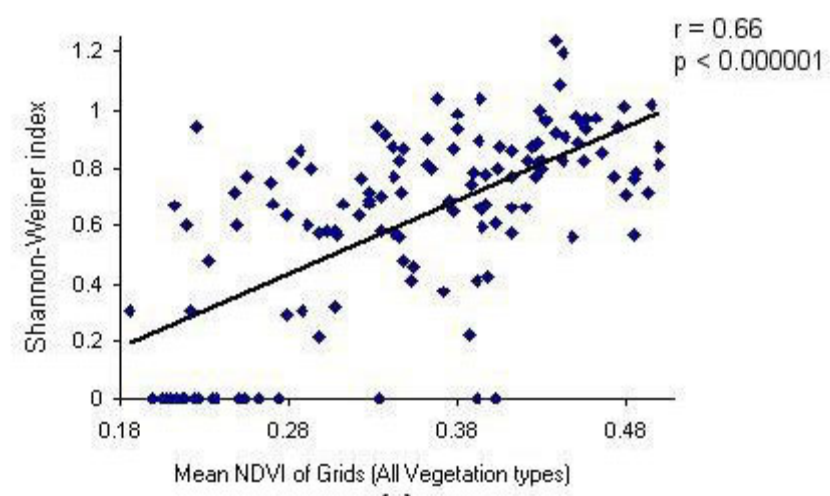

(a)

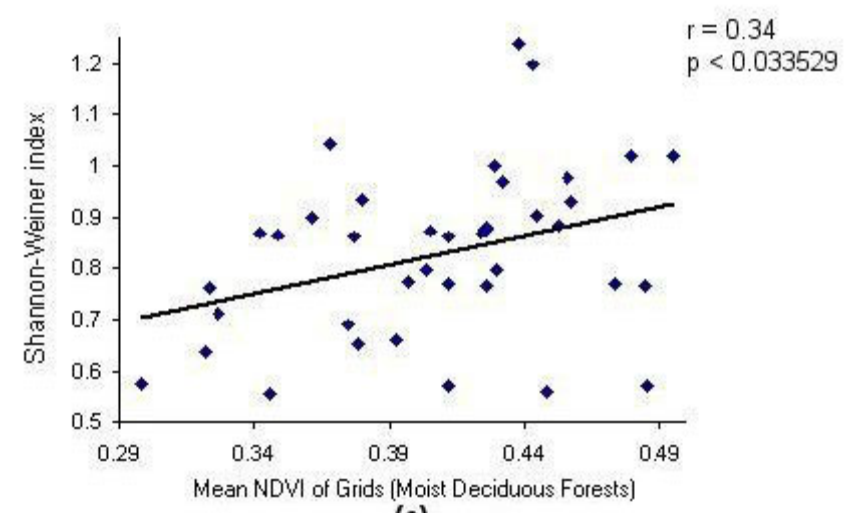

(c)

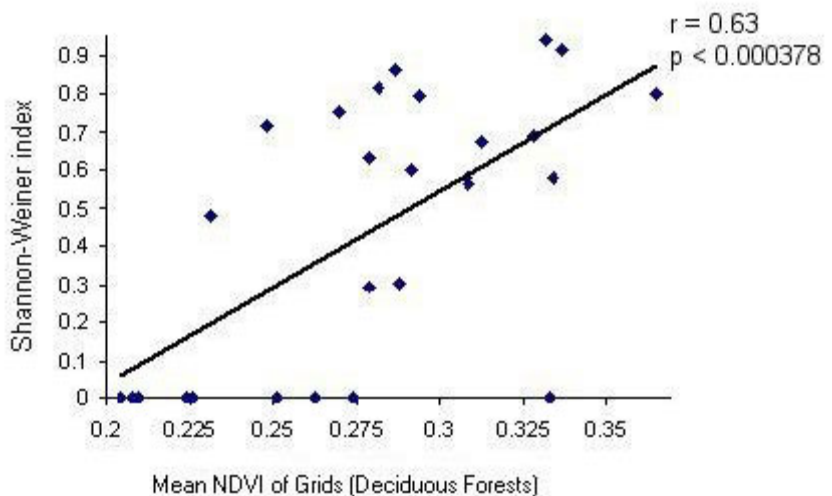

(b)

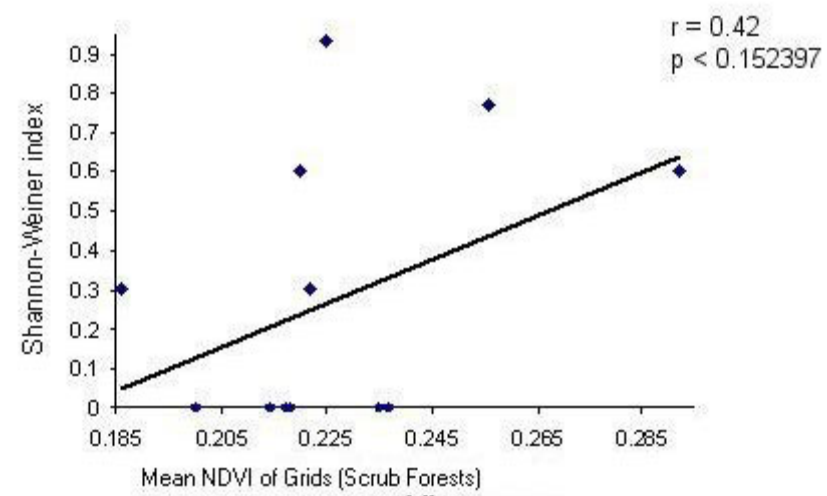

(d) 
Species diversity (Shannon and Weiner 1963) was determined for 134 cells in $80 \times 5$-m plots laid in the center of each cell. Plot size was determined by time available for sampling all plots (one year) and the size needed to adequately capture tree species richness of various vegetation types. All trees greater than $10 \mathrm{~cm}$ diameter at breast height (dbh) were enumerated and totaled for each cell. Index was calculated by using the formula: $-\sum\left(\mathrm{n}_{\mathrm{i}} / \mathrm{N}\right) \log { }_{10}\left(\mathrm{n}_{\mathrm{i}} / \mathrm{N}\right)$, where $\mathrm{n}_{\mathrm{i}}$ is the importance value of each species and $\mathrm{N}$ is the total importance value (i.e., 300).

Fig. 2. Scattered distribution of evergreen forests and grasslands in various cells.

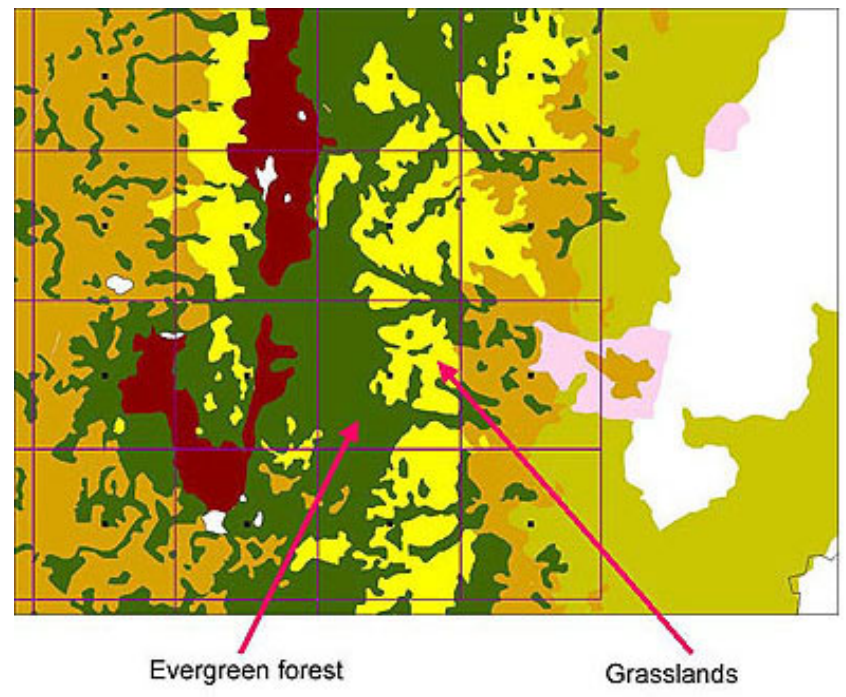

\section{RESULTS AND DISCUSSION}

The basic parameters of each forest type found on the study site, such as basal area, average number of individuals, and average number of tree species, are shown in Table 1 . The greatest species richness was found in the evergreen forests.

There was a positive correlation between mean NDVI and tree species diversity for all cells, without considering the vegetation types (Fig. 1a). Analysis for each of the four vegetation types revealed a positive correlation for deciduous (Fig. 1b) and moist deciduous forest (Fig. 1c). For the scrub forest, the relationship was positive (Fig. 1d), but not significant. The non significance could be due to the small sample size for the scrub forest. A separate analysis was not done for the evergreen forest because it is found in patches of various sizes interspersed in high-altitude grasslands that have relatively low NDVI values (Fig. 2). Thus, the mean NDVI of the grid is not representative of the evergreen forests. Furthermore, in evergreen forests, NDVI values quickly get saturated after a certain number of species accumulates (Arturo Sanchez, personal communication).

Previous workers have found that an annual sum of NDVI derived from satellite imagery, and weighted with parameters for radiation absorption and light-use efficiency, may be used to estimate primary productivity at global and regional scales (Runyon et al. 1994, Tucker and Sellers 1986). As there is a wellknown relationship between species richness and productivity (Adams and Woodward 1989, Currie 1991), we expected a positive relationship between plant species richness and NDVI values.

Indeed our results demonstrate that NDVI from remotely sensed images could identify areas of high species richness (Fig. 3). The two images in Fig. 3 are visually similar.

These results are not surprising because the NDVI should reflect the productivity of the ecosystem or the availability of free energy. Indeed both productivity and availability of energy are assumed to be the major determinants of species richness (Adams and Woodward 1989, Currie 1991, Rosenzweig and Abramsky 1993, Currie and Paquin 1987). However, despite the well-established relationship between productivity and species richness, remotely sensed imagery that can detect differences in measures of productivity has not previously been used to assess biodiversity. We should caution here that, as NDVI is a reflection of productivity or biomass, plantations or other human-managed ecosystems on the landscape can complicate the patterns described here.

The NDVI may be used not only to detect spatial patterns of biodiversity but also the distribution of biophysical parameters. The differences in vegetation type are primarily due to variation in soils, moisture, and temperature. Further analysis of the exact relationship between vegetation types and NDVI may lead to the detection of variation in biophysical parameters from satellite imagery.

The urgent need for knowledge about biodiversity distribution over large areas of the globe, as emphasized by Wilson (2000), requires the use of remotely sensed imagery to identify areas of high species richness over large landscapes. We have 
demonstrated that satellite imagery can identify broad patterns of tree species diversity in tropical forests. We recognize that the identification of such patterns must be followed by detailed work on the ground to confirm the trends and to document precisely the distribution of the biodiversity.

Responses to this article can be read online at:

http://www.consecol.org/vol6/iss2/art7/responses/index.html.

Fig. 3. NDVI and tree-species diversity in the Biligiri Rangaswamy Temple Wildlife Sanctuary.

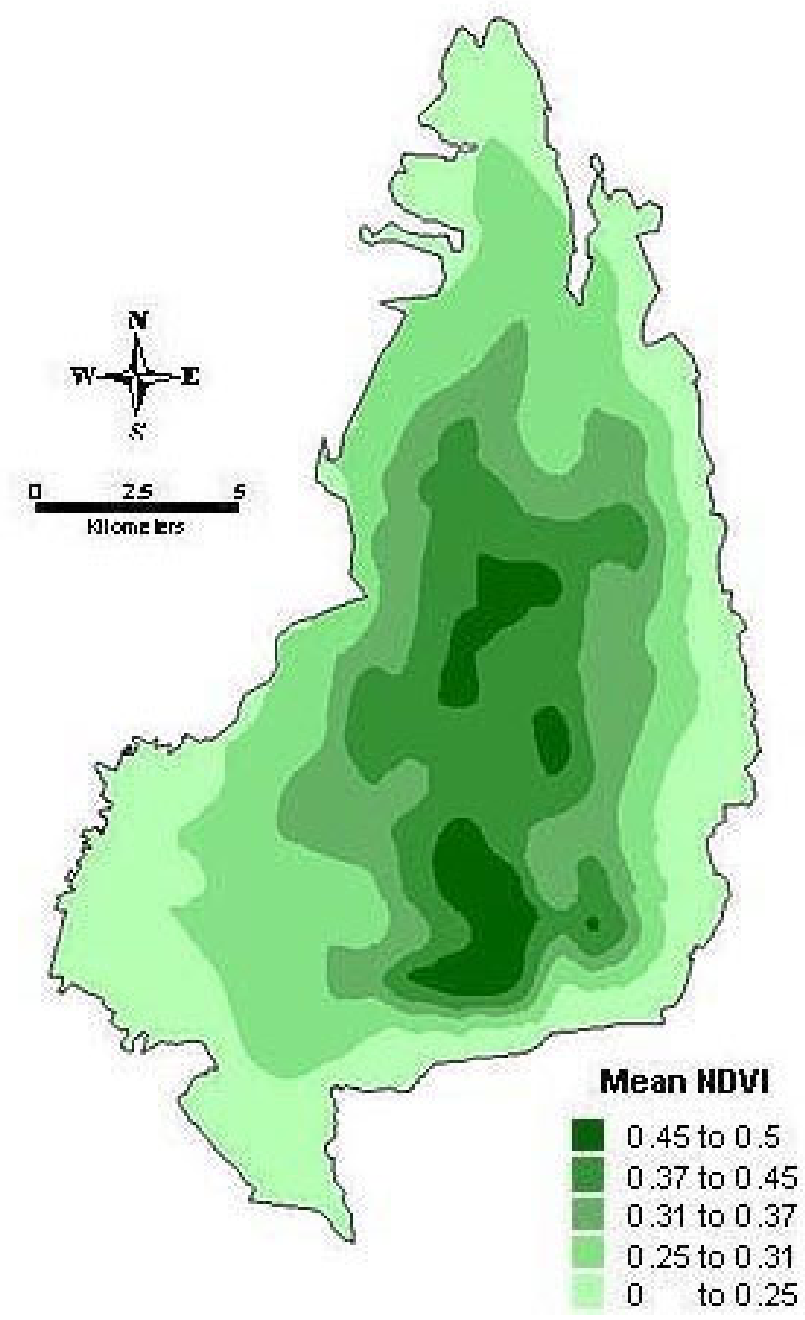

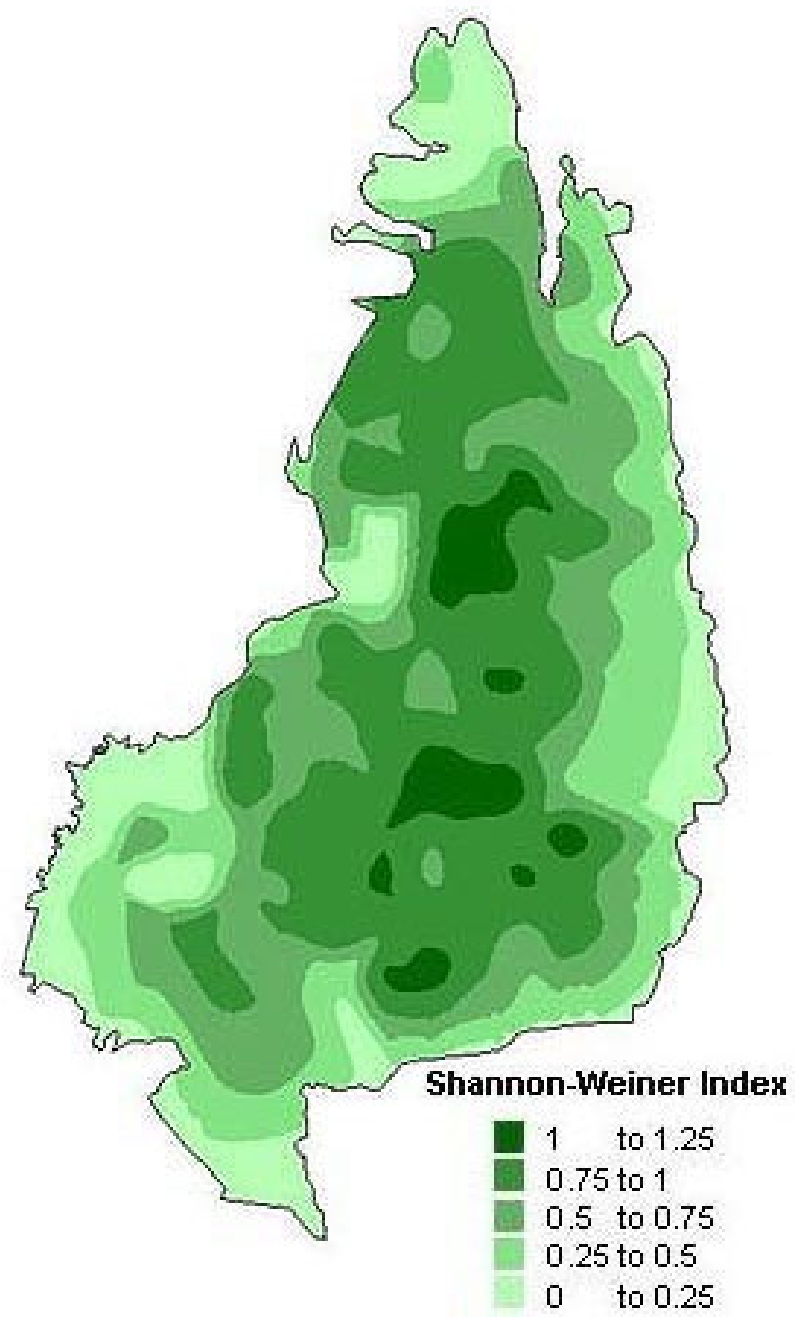

\section{Acknowledgments:}

We thank Arturo Sanchez and Jagdish Krishnaswamy for their advice and help with various analyses. Financial support was provided by grants from the Ford Foundation and the MacArthur Foundation.

\section{LITERATURE CITED}

Adams, J. M., and F. I. Woodward. 1989. Patterns in tree species richness as a test of the glacial extinction hypothesis. Nature 339:699-701.
Currie, D. J. 1991. Energy and large-scale patterns of animal and plant species richness. American Naturalist 137:27-49.

Currie, D. J., and V. Paquin. 1987. Large scale biogeographical patterns and species richness of trees. Nature 329:326-327

Food and Agriculture Organization (FAO). 2000. Global Forest Resources Assessment 2000. United Nations, Rome, Italy.

Rosenzweig, M. L., and Z. Abramsky. 1993. How are diversity and productivity related? Pages $52-65$ in R. E. 
Rixklefs and D. Schluter, editors. Diversity in Ecological Communities. University of Chicago Press, Chicago, Illinois, USA.

Runyon, J. R., H. Waring, S. N. Goward, and J. M. Welles. 1994. Environmental limits on net primary production and light-use efficiency across the Oregon Transect. Ecological Applications 4: 226-237.

Tucker, C. J., and P. J. Sellers. 1986. Satellite remote sensing of primary production. International Journal of Remote Sensing 7:1395-1416.

Shannon, C. E., and W. Weiner. 1963. The Mathematical Theory of Communication. University of Illinois Press, Urbana, Illinois, USA.

Walter, K. S., and J. H. Gillett. 1998. 1997-IUCN Red List of Threatened Plants. IUCN (1998).

Wilson, E. O. 2000. A global biodiversity map. Science 289:2279. 